\title{
Treatment of Periodontal Intraosseous Lesions with the use of Biomaterials: A Review
}

Lara Mendes Guedes ${ }^{1}$, Bruna Murad ${ }^{1}$, Idiberto José Zotarelli Filho ${ }^{2 \star}$, Leandro Moreira Tempest ${ }^{1,2}$, Carlos Alberto Costa Neves Buchala ${ }^{2}$ and Patrícia Garani Fernandes ${ }^{1,2}$

${ }^{1}$ University Center North Paulista (Unorp) - São José do Rio Preto - SP, Brazil

${ }^{2}$ Post graduate and continuing education (Unipos), Street Ipiranga, 3460, São José do Rio Preto SP, Brazil 15020-040

\begin{abstract}
Background: Bacterial plaque is one of the main cofactors that lead to destruction of the periodontium of protection and support, causing bone defects. For the treatment of these lesions, biomaterials are used that have as main characteristic the biocompatibility, being able to be of origin: autogenous, homologous or alógenous and heterogenous or xenógenous. They are used for the purpose of inducing repair and bone formation, being called guided tissue regeneration.

Methodology: Experimental and clinical studies were included (case reports, retrospective, prospective and randomized trials) with qualitative and / or quantitative analysis. The words were included Bone grafts, guided tissue regeneration, periodontitis, biocompatibility and surgery. A total of 70 articles were found involving guided tissue regeneration and surgery. After this process, the summaries were evaluated and a new exclusion was held. A total of 40 articles were evaluated in full, and 28 were included and discussed in this study.
\end{abstract}

Conclusion: Because biological properties in bone graft there is a technological growth of these biomaterials because they are pointed to the potential tools for the treatment of bone loss.

Keywords: Bone grafts; Guided tissue regeneration; Periodontitis; Biocompatibility and surgery

\section{Introduction}

The bacterial plaque is considered one of the main factors detrimental to the periodontium. This can generate inflammatory processes that will impair the structures of support and protection of the dental element, which can lead to a loss of bone and, over time and intensity of the disease, can lead to tooth loss.

Periodontitis is a chronic and infectious disease that affects the soft and hard periodontal tissues responsible for supporting and sustaining the dental element and may be closely associated with systemic diseases such as diabetes and cardiac problems that can aggravate the existing disease, Periodontitis, as altered glycemic value, and cardiological disorders, due to effects on the immunological and inflammatory mechanisms, which should be treated palliatively in these cases $[1,2]$.

Periodontitis causes loss of bone support, consequently gingival recession having multifactorial reasons [3]. It is characterized clinically as the gingival migration of the amelo-cement margin to the apical direction, causes accumulation of food in the area, increasing the chances of caries, negatively affects aesthetics, and increased hypersensitivity [4].

During the use of the biomaterials we must take into account its biocompatibility, toxicity, and its carcinogenic or radiative power [5-8]. Biomaterials are used in an attempt to recover lost periodontal tissues.

In order to obtain a positive result, we must evaluate and take into account lesion characteristics such as: depth, width, volume, texture, as well as to analyze the control of etiological factors and clinical skills, in order to conclude the best type of procedure and the best material to be used. In addition, for each case, systemic conditions and patient hygiene should be analyzed in order to achieve treatment success and a good prognosis [6-9]. There is a wide variety of materials to be selected for treatment of bone lesions, based on the choice of the intensity of the bone defect [10].

The objective of the present study was to report, through the literature review, the use of biomaterials and promising techniques indicated for the treatment of periodontal bone lesions, highlighting the advantages and disadvantages of the use of each material having as main objective, to provide a good prognosis for the patient.

\section{Methodology}

Experimental and clinical studies were included (case reports, retrospective, prospective and randomized trials) with qualitative and / or quantitative analysis. Initially, the key words were determined by searching the DeCS tool (Descriptors in Pubmed, Health Sciences, BIREME base) and later verified and validated by MeSh system (Medical Subject Headings, the US National Library of Medicine) in order to achieve consistent search.

\section{Mesh terms}

The words were included Bone grafts, guided tissue regeneration, periodontitis, biocompatibility and surgery. The literature search was conducted through online databases: Pubmed, Periodicos.com and Google Scholar. It was stipulated deadline, and the related search covering all available literature on virtual libraries.

\section{Series of articles and eligibility}

A total of 70 articles were found involving guided tissue regeneration and surgery. Initially, it was held the exclusion existing title and

*Corresponding author: Prof. Dr. Idiberto José Zotarelli Filho, Unipos - Post graduate and continuing education, Street Ipiranga, 3460, São José do Rio Preto SP, Brazil 15020-040, Tel: +55(17) 98166-6537/ +55(17) 98803-7459; E-mail: m.zotarelli@gmail.com

Received April 27, 2018; Accepted May 18, 2018; Published May 21, 2018

Citation: Guedes LM, Murad B, Filho IJZ, Tempest LM, Buchala CACN, et al. (2018) Treatment of Periodontal Intraosseous Lesions with the use of Biomaterials: A Review. Dentistry 8: 489. doi:10.4172/2161-1122.1000489

Copyright: (c 2018 Guedes LM, et al. This is an open-access article distributed under the terms of the Creative Commons Attribution License, which permits unrestricted use, distribution, and reproduction in any medium, provided the original author and source are credited. 
duplications in accordance with the interest described this work. After this process, the summaries were evaluated and a new exclusion was held. A total of 40 articles were evaluated in full, and 28 were included and discussed in this study.

\section{Literature review and discussion}

Periodontal therapies have as their main characteristic, to return the functionality and health of these structures and to form new tissues that were lost during periodontitis [1-3]. Among the most requested characteristics are: Biocompatibility, ease of application providing a safe operative and favorable prognosis [4,7].

In view of the many biomaterials possible to use, all present the purpose of the induction and proliferation of osteoblastic cells at the site of periodontitis, so that bone production increases and corrects the local bone defects, being called as guided tissue regeneration [8]. These materials can be subdivided into osteoinducers, and osteoconductors. Osteoinducers induce the differentiation of undifferentiated mesenchymal cells into osteoblast cells, thereby increasing and stimulating bone formation [9-12]. Osteoconductors through cell proliferation ensure the deposition of new bone tissue at the site.

Biocompatible materials are indicated as having the ability to induce faster bone repair [11-15]. Among the materials most used for the treatment of bone regeneration, we highlight the use of autogenous, homogenous or allogeneic, heterogenous or xenogenous grafts [16].

Although autogenous are considered the best option because it presents a good biocompatibility and to be osteoinductive, the fact that it requires a second surgical area, makes the use of xenogens and allogene grafts to be highlighted, being a great option for the treatment of guided bone regeneration, Mainly because it does not require a second surgical area, giving the patient a better postoperative period $[7,17]$.

Autogenous grafts are removed from the person receiving the donor material, they have a higher biocompatibility, besides being osteoinductors, osteoconductors and osteogens, but they present more negative characteristics because they require a donor area requiring a second surgery, obtaining donor material Limited, increased cost, recovery time and possibility of inflammation $[3,18]$.

Homogenous or allogeneic grafts are removed from a person and re-implanted in the same species. However, they have different genetic characteristics, increasing the risk of contamination and inflammation, and requiring greater care in the handling and storage of the material [3,18-20].

The heterogenous or xenogenous grafts, is a material removed from one species and reimplanted in another, also obtaining different genetics, has the advantage of not having another surgery in the individual, being possible to find the industrialized material and at low cost, reducing the chances of contamination and inflammation, providing a good prognosis [21].

The bovine grafts are classified as organic and inorganic; The organic ones have higher concentration of protein rich in type I collagen, since the inorganic one has absence of protein and being rich in hydroxyapatite (Table 1) $[3,21,25]$.

\begin{tabular}{|c|c|c|}
\hline Author & Year & Conclusion \\
\hline Tonetti et al. [10] & 1993 & $\begin{array}{l}\text { Guided tissue regeneration (GTR) treatment was observed in cases of deep periodontal lesions, taking into account the characteristics } \\
\text { of the case and the surgical parameter used before and after removal of the membrane; It was verified that with the use of membrane } \\
\text { there was an accentuated tissue gain and the level of insertion of regenerated probe. }\end{array}$ \\
\hline Goissis et al. [22] & 1999 & $\begin{array}{l}\text { It is concluded that hydrolyzed anionic collagen membranes are a good material to be used for their excellence in biocompatibility and } \\
\text { biodegradation, but it has been observed that their use is indicated for injured sites but also in any place that requires the biodegradability } \\
\text { of the material. }\end{array}$ \\
\hline Scheyer et al. [11] & 2002 & $\begin{array}{l}\text { The study followed } 17 \text { people with atrial problems and depth of probing greater than or equal to } 5 \mathrm{~mm} \text { and with chronic periodontitis, } \\
\text { divided into two treatment groups, with EMD (derived from emerald matrix protein) associated with BDX (bovine bone xenograft And } \\
\text { another with only BDX, it was concluded that, although both had good efficacy and good results, the EMD associated with BDX obtained } \\
\text { a higher regeneration. }\end{array}$ \\
\hline Trombelli et al. [14] & 2002 & $\begin{array}{l}\text { Specific biological biomaterials have been shown to be more effective when compared to the use of biological agents with open-flap } \\
\text { debridement due to the fact that the biological biomaterials present an improvement in the insertion levels. Biomaterials such as } \\
\text { hydroxyapatite, bilative glass and calcium carbide are classified as good materials used in bone regeneration. }\end{array}$ \\
\hline Scabbia e Tronbelli [15] & 2004 & $\begin{array}{l}\text { Two types of treatment with biomateials were deployed: synthetic type I collagen / chondroitin sulfate }(\text { Biosite } ®) \text { and a bovine-derived } \\
\text { xenograft }(\text { Bio-Oss } \AA) \text { in deep intra-osseous defects, after the operation of } 24 \text { patients in the range Age group of } 30 \text { to } 64 \text { years and of } \\
\text { female and male gender, } 11 \text { were treated with Bio-Oss } ₫ \text { and } 13 \text { with Biosite } ₫ \text {, analyzing pre-surgical clinical and radiographic exams } \\
\text { and after } 12 \text { months, there was no difference in the regeneration of the two groups. }\end{array}$ \\
\hline Nevins et al. [21] & 2005 & $\begin{array}{l}\text { They carried out a study on the efficacy of the use of purified recombinant human platelets mixed with a synthetic beta tricalcium } \\
\text { phosphate, and resulted in a decrease in gingival recession and increased insertion levels, showing to be a good material to be used } \\
\text { for infra-osseous lesions. }\end{array}$ \\
\hline Fófano et al. [7] & 2005 & $\begin{array}{l}\text { In view of the different biomaterials indicated for the treatment of bone regeneration, we highlight the use of autogenous, homologous } \\
\text { or allogeneic grafts and the heterogenous or xenogenic grafts. Although the use of autogenous grafts is considered a good option for } \\
\text { this type of treatment mainly because it presents important characteristics such as biocompatibility and osteoinduction, the fact that it } \\
\text { requires a second surgical area ends up making the patient's treatment and postoperative difficult, Restricted. Among the materials that } \\
\text { present a good option for the treatment of guided tissue regeneration, the use of xenogene or allogene grafts is highlighted. These have } \\
\text { the ability to be osteoinductive or osteoconductive in which they are important characteristics to be successful in this type of treatment. }\end{array}$ \\
\hline Bon et al. [1] & 2005 & $\begin{array}{l}\text { Dermal matrix grafts have been highlighted, compared to the use of autogenous soft tissue grafts, due to the fact that they present } \\
\text { features, advantages and similarities to this material, such as: recession reduction, increased keratinized tissue width and clinical } \\
\text { insertion gain, The main advantage is that it does not require a second surgical area. Having as disadvantage its high cost, making its } \\
\text { use still be restricted. }\end{array}$ \\
\hline
\end{tabular}


Citation: Guedes LM, Murad B, Filho IJZ, Tempest LM, Buchala CACN, et al. (2018) Treatment of Periodontal Intraosseous Lesions with the use of Biomaterials: A Review. Dentistry 8: 489. doi:10.4172/2161-1122.1000489

\begin{tabular}{|c|c|c|}
\hline Geisinger et al. [12] & 2007 & $\begin{array}{l}\text { The use of the fiberoptic periodontal endoscope was studied to help in the definitive diagnosis and treatment of periodontal disease. } \\
\text { Fifteen patients with fifty pairs of teeth were analyzed, they were prepared to receive the SRP in the absence and presence of the } \\
\text { endoscope, after extracting the elements it was noticed that the percentage of residual calculus present was smaller with the use of } \\
\text { the endoscope at greater depths. }\end{array}$ \\
\hline Piemontese et al. [9] & 2008 & $\begin{array}{l}\text { Sixty subjects with chronic periodontitis and nonsmokers, treated with platelet-concentrated plasma (PRP) associated with demineralized } \\
\text { linfilified bone allograft (DFDBA), and DFDBA associated with saline solution were monitored. It was concluded that the PRP option } \\
\text { associated with DFDBA was Although the two had a good prognosis. }\end{array}$ \\
\hline Liu et al. [17] & 2008 & $\begin{array}{l}\text { Through a test the application of autologous stem cells of the periodontal ligament (PDLSCs) was carried out with the purpose of } \\
\text { analyzing the chance of success in the treatment and the capacity of regeneration of the biomaterial. An injury was generated by } \\
\text { removal of the bone in the region of the first molar and later cells of PDLSCs were transplanted to the same region, which obtained } \\
\text { a satisfactory result for having presented the regeneration of the periodontal tissues, becoming a favorable biomaterial to be used as } \\
\text { Treatment of bone regeneration in periodontal defects. }\end{array}$ \\
\hline Santana et al. [23] & 2009 & $\begin{array}{l}\text { There is a great difficulty of bone regeneration in the furcation area, in this study } 60 \text { patients were evaluated, divided into two groups } \\
\text { where one received experimental combined regenerative therapy (ET), compared to open-flap debridement (OFD) in ET gave (3: } 1 \text { ), } \\
\text { comparing it was noted that the group that received the compound had a clinical improvement and increased regenerative growth. }\end{array}$ \\
\hline Rodrigues et al. [2] & 2010 & $\begin{array}{l}\text { The use of the subepithelial connective tissue graft has been shown to be a promising biomaterial used for the treatment of root } \\
\text { coverage due to its bilaminar character. Several factors may be correlated to achieve ultimate success in treatment. We must be } \\
\text { attentive to the characteristics of the lesion as: depth, width, volume, texture, graft color, vascularization and presence of scars, taking } \\
\text { into account also the etiological factors and the clinical abilities to be able to conclude the best type of procedure and which And the } \\
\text { most indicated biomaterial to be used. }\end{array}$ \\
\hline Verríssimo et al. [19] & 2010 & $\begin{array}{l}\text { It was concluded that through the crosslinking of glutaraldehyde in a polyanionic mineralized collagen membrane, it shows a smaller } \\
\text { inflammatory response and less biodegration of the membranes when compared to the use of membranes without crosslinking, making } \\
\text { it a good treatment option for lesions where the dental element Needs a bone production that depends on the use of a mechanical } \\
\text { barrier. }\end{array}$ \\
\hline Struillou et al. [16] & 2010 & $\begin{array}{l}\text { Despite being of different anatomy and pathophysiology, they are used to model the diseases and treatments to be used, although } \\
\text { several species of animals are used, such as monkeys, dogs, hamsters, Rabbits and etc., research on dogs and monkeys are more } \\
\text { restricted, being more suitable for this type of research hamster and mice. }\end{array}$ \\
\hline Struillou et al. [24] & 2011 & $\begin{array}{l}\text { A research was performed to analyze bone regeneration with the siliconized compound methyl acellulose (Si-HPMC) / biphasic calcium } \\
\text { phosphate and biphasic calcium phosphate (BCP), observed in three months, the use of BCP has better efficacy in Furcation region, } \\
\text { already in the healing control both Si-HPMC and BCP are effective; Easy to use material but requires further research to improve the } \\
\text { properties of the material, thus improving its results. }\end{array}$ \\
\hline Ayub et al. [3] & 2011 & $\begin{array}{l}\text { Because non-biodegradable membranes and polytetrafluoroethylene membranes are widely used and require a second surgical } \\
\text { area, it has favored the use of new techniques and materials to be developed and used. The polytetraflourethylene membranes are } \\
\text { being replaced by collagen membranes because these membranes do not require a second surgical area, they present a good bone } \\
\text { regeneration. The choice of material and the technique used should be selected by the professional individualizing the case, always } \\
\text { thinking of a positive prognosis. }\end{array}$ \\
\hline karma et al. [20] & 2011 & $\begin{array}{l}\text { The use of autogenous fibrin, a material rich in platelets, has been shown to be a great option for the treatment of intra-auricular defects } \\
\text { in patients with chronic periodontitis. Through the research it was analyzed that autogenous fibrin provided a reduction of probing } \\
\text { depth, periodontal insertion level and increased bone filling in patients who were treated with conventional open-flap debridement when } \\
\text { compared to the treatment performed in patients with flap debridement Conventional alone. However, although this treatment showed } \\
\text { a great clinical and radiographic effectiveness, there should be a long-term follow-up and control by analyzing the clinical effects of this } \\
\text { biomaterial [25]. }\end{array}$ \\
\hline Dantas et al. [8] & 2011 & $\begin{array}{l}\text { Several methods have been used in the effort to reconstruct periodontal structures, the most frequently used are bone grafts and guided } \\
\text { tissue regeneration (GTR); The success index is closely linked to the skill and competence of the professional, following post-surgical } \\
\text { guidelines, degree of defect invasion, anatomical characteristics, and patient habits. Therefore, the surgical technique and the choice } \\
\text { of the biomaterial should be selected by the professional with great caution, individualizing the case and thinking about the positive } \\
\text { prognosis. }\end{array}$ \\
\hline Galdeano et al. [5] & 2014 & $\begin{array}{l}\text { The use of elastin membranes derived from bovine atrial cartilage has been shown to be a promising material used in bone regeneration } \\
\text { therapies. The elastin membrane has a wide biodegradability making it possible to replace the implanted material by neoformate } \\
\text { bone, in addition, it provides support for cell proliferation and is capable of generating immune responses that will facilitate tissue } \\
\text { regeneration. This biomaterial presents important characteristics such as osteoinduction, osteoconduction and biocompatibility. Its use } \\
\text { is more indicated than the other biomaterials of autogenous origin because it does not require a second surgical area, providing a better } \\
\text { prognosis for the patient. }\end{array}$ \\
\hline Figliuzzi et al. [26] & 2014 & $\begin{array}{l}\text { A total of } 100 \text { patients with a gingival pouch of at least } 10 \mathrm{~mm} \text { were evaluated. Surgeries with a stoichiometrically unstable (absorbable) } \\
\text { synthetic biomaterial, based on hydroxyapatite (Engipore), were observed at one year and great bone formation was observed in the } \\
\text { Local, and bone integration of great effectiveness, high effectiveness material. }\end{array}$ \\
\hline Paul et al. [18] & 2014 & $\begin{array}{l}\text { In the study done between periodontal regeneration with mesenchymal stomatal cells (MSC'S) in animals, it was not very successful, } \\
\text { because there were marked differences between the experimental and control groups, and the animal pathophysiology differs from the } \\
\text { human. It is suggested that groups of future studies investigate rodents for defects to be passed with more precision to the inflammatory } \\
\text { transition and the pathogenic microbiota. It is recommended that the study and lineage should be refined for testing before transferring } \\
\text { to clinical cases. }\end{array}$ \\
\hline
\end{tabular}


Citation: Guedes LM, Murad B, Filho IJZ, Tempest LM, Buchala CACN, et al. (2018) Treatment of Periodontal Intraosseous Lesions with the use of Biomaterials: A Review. Dentistry 8: 489. doi:10.4172/2161-1122.1000489

\begin{tabular}{|l|l|l|}
\hline Fernandes et al. [28] & 2015 & $\begin{array}{l}\text { Eight patients with eighteen bone defects were analyzed and followed up using emerald matrix derived biomaterial (EMD) with or } \\
\text { without synthetic bone substitute (Bone Ceramic), observing the two groups obtained a reduction in the depth of probing and showed } \\
\text { improvement compared to that of lineage Base, although the regenerative procedure with EMD associated with Bone Ceramic obtained } \\
\text { better filling of the bone defects. }\end{array}$ \\
\hline Qasim et al. [27] & 2015 & $\begin{array}{l}\text { Guided tissue regeneration membranes (RTGs), which are not biodegradable, require a second surgery for their removal using porous } \\
\text { chitosan (CH) membranes, with or without hydroxyapatite (HA) substance, using simple form Chilled freezing (FG) from two depleted } \\
\text { solvents, acetic acid (Aca) or ascorbic acid (Asa), human embryonic stem cells (hES-MPs) proved that cell duplication is greater with } \\
\text { the use of membrane composed of CH and HA and FG membranes could be added to potentiate cell proliferation, causing greater } \\
\text { regeneration. }\end{array}$ \\
\hline Vieira et al. [6] & 2015 & $\begin{array}{l}\text { Porcine graft grafts have been proven in studies, numerous benefits such as: keratinized tissue augmentation, alveolar closure and root } \\
\text { coverage, which are essential characteristics to obtain a good prognosis. }\end{array}$ \\
\hline
\end{tabular}

Table 1: Main references on the use of periodontal intraosseous lesions with the use of biomaterials.

\section{Conclusion}

Biological properties in bone graft there have a technological growth of these biomaterials because they are pointed as potential tools for the treatment of bone loss. It is necessary for the professional to be careful in its use by assessing the advantages and disadvantages by means of prospective and randomized clinical studies and with increase of size sample.

\section{Conflict of Interests}

There is no conflict of interest between authors.

\section{References}

1. Bon CG de (2005) Use of acellular dermal matrix for root coverage. Gaucho Journal of Dentistry 53: 124-127.

2. Rodrigues DC, Alves R, Second TK (2010) Use of the subepithelial conjutive tissue graft in the root covering. Gaúcha de Odontologia Magazine 58: 115-118.

3. Ayub LG (2011) Guided bone regeneration and its therapeutic applications. Sobrape Magazine 21: 24-31.

4. Neto RS (2008) Chitosan - based biomaterials with medical and dental application: literature review. Journal of Dentistry 37: 155-161.

5. Galdeano EA (2014) Elastin membrane derived from atrial cartilage in bone regeneration therapies. Xxiv Brazilian Congress of Biomedical Engineering 1: 2013-2016.

6. Vieira GHA (2015) Swine collagen matrix for the treatment of gingival retraction. Sobrape Magazine 25: 41-46.

7. Fófano G (2005) Regenerative Periodontal Treatments in Dogs: Literature Review. Ceres Magazine 52: 447-452.

8. Dantas TS (2011) Bone graft material and its applications in dentistry. Unopar Scientific 13: 131-135.

9. Piemontese M, Aspriello SD, Rubini C, Ferrante L, Procaccini M (2008) Treatment of periodontal intra-auricular defects with dehydrated and dehydrated bone allograft in combination with platelet-rich plasma: A clinical and comparative trial. J Periodontol 79: 802-810.

10. Tonetti MS, Pini-Prato G, Cortellini P (1993) Periodontal Regeneration of Human Intrabony Defects: Determinants of the Cure Response. J Periodonto 64: $934-940$

11. Scheyes TE, Velasquez-Plata D, Brunsvold MA, Lasho DJ, Mellonig JT (2002) A clinical comparison of a bovine derived Xenograft used alone and in combination with the enamel matrix derivative for the treatment of periodontal bone defects in humans. J Periodontol 73: 423-432.

12. Geisinger ML, Mealey BL, Schoolfield J, Mellonig JT (2007) The efficacy of the subgingival scale and root planing: An evaluation of therapy with and without the use of periodontal endoscopy. J Periodontol 78: 22-28.

13. Novak MJ, Johns LP, Miller RC, Bradshaw MH (2002) Supplementary benefits of doxycycline subantimicrobial dose in the treatment of severe and generalized chronic periodontitis. J Periodontol 73: 762-769.
14. Trombelli L, Heitz-Mayfield LJ, Needleman I, Moles D, Scabbia A, et al. (2002) A systematic review of graft materials and biological agents for intraosseous periodontal defects. J Clin Periodontol 29: 117-135.

15. Scabbi A, Trombelli $L$ (2004) A comparative study on the use of a biomateria $\mathrm{HA} /$ collagen/chondroitin sulfate (Biotite $\AA$ ) and bovine $\mathrm{HA}$ xenograft (Bio-oss $\AA$ ) in the treatment of deep intra-osseous defects. J Clin Periodontol 31: 348-355.

16. Struillou X, Boutigny $H$, Soueidan A, Layrolle $P(2010)$ Experimental models of animals in periodontics: A review. Open Dent J 4: 37-47.

17. Liu Y, Zheng Y, Ding G, Fang D, Zhang C, et al. (2008) Periodontal ligament treatment mediated by stem cells for periodontitis in miniature swine. Stem Cells, Durham 26: 1065-1073.

18. Monsarrat P, Vergnes JN, Nabet C, Sixou M, Snead ML, et al. (2014) Mesenchymal stromal cells used for periodontal regeneration: A Systematic Review. Stem Cells Transl Med 3: 768-774.

19. Veríssimo DM, Leitão RF, Ribeiro RA, Figueiró SD, Sombra AS, et al. (2010) Polyanionic polygenic membranes for guided tissue regeneration: Effect of progressive glutaraldehyde crosslinking on biocompatibility and degradation. Acta Biomater 6: 4011-4018.

20. Sharma A, Pradeep AR (2011) Treatment of intra-auricular defects in patients with chronic periodontitis with autologous platelet-rich fibrololysis: A clinical trial. Journal of Periodontology Online, Chicago 82: 1705-1712.

21. Nevins M, Giannobile WV, McGuire MK, Kao RT, Mellonig JT, et al. (2005) Platelet-derived growth factor stimulates bone filling and the rate of increase of attachment levels: results of a large multicenter randomized controlled trial. $\mathrm{J}$ Periodontol 76: 2205-2215.

22. Goissis G, Juniora EM, Marcantônioa RAC, Lia RCC, Cancian DCJ, et al. (1999) Biocompatibility studies of anionic collagen membranes with different degrees of glutaraldehyde cross-linking. Biomaterials 20: 27-34.

23. Santana RB, de Mattos CM, Van Dyke T (2009) Efficacy of combined regenerative treatment in class II human jaw furcation defects. J Periodontol 80: 1756-1764.

24. Struillou $X$ (2011) Treatment of periodontal defects in dogs using a hydroge injectable compost/biphasic calcium phosphate. Journal of Materials Science: Materials in Medicine 22: 1707-1717.

25. Mardas N, Dereka X, Donos N, Dard M (2013) Experimental model for bone regeneration in oral and cranio-maxillofacial surgery. J Invest Surg 27: 32-49.

26. Figliuzzi MM (2014) Histological evaluation of a biomimetic material on bone regeneration after one year of the graft. Annali di Stomatologia, Rockville Pike 5: 103-107.

27. Qasim SB, Delaine-Smith RM, Fey T, Rawlinson A, Rehman IU (2015) Freeze gaseous porous membranes for regeneration of periodontal tissue. Acta Biomaterialia 23: 317-328.

28. Fernandes PG (2015) Periodontal Intra-auricular Defects and Treatment with Enamel Matrix Derivative and a Synthetic Bone Substitute in Humans: A Clinical and Radiographic Series. J Interdiscipl Med Dent Sci 3: 1-5. 